\title{
MOTIVASI KERJA ISLAM DAN ETOS KERJA ISLAM KARYAWAN BANK JATIM SYARIAH CABANG SURABAYA 11
}

Bhirawa Anoraga

Mahasiswa Program Studi S1Ekonomi Islam - Fakultas Ekonomi dan Bisnis-Universitas Airlangga Email: birawadedogol@yahoo.com

Ari Prasetyo

Departemen Ekonomi Syariah - Fakultas Ekonomi dan Bisnis - Universitas Airlangga

Email: ari_feunair@yahoo.co.id

\begin{abstract}
:
This research was aimed to investigate the effect of Islamic work motivation to the employee Islamic work ethics on Jatim Sharia Bank Branch Surabaya. This study used questionnaires in primary data collection and quantitative approaches. Experiments were done using simple linear regression, where the dependent variable $(Y)$ is the employee Islamic work ethics and the independent variable $(X)$ is Islamic work motivation. The research sample were taken by census. The research sample was 54 employees working in Jatim Sharia Bank Branch Surabaya.

Based on the findings, it obtained simple linear regression equation: $Y=2,739+0,353 X$. The magnitude of the influence of Islamic work ethics to the employees Islamic work ethics on Jatim Sharia Branch Surabaya is the $R^{2}$ value of $0,446(44,6 \%)$. The result show that employee Islamic work ethics on Jatim Sharia Bank Branch Surabaya significantly affect by Islamic work motivation.
\end{abstract}

Keywords : Islamic Work Motivation, Employee Islamic Work Ethics

\section{PENDAHULUAN}

\section{Latar Belakang}

Sumber daya manusia (SDM) merupakan aset utama dan besar pengaruhnya terhadap kemajuan suatu perusahaan. Untuk mencapai apa yang telah menjadi tujuan perusahaan yang telah ditetapkan, maka perusahaan harus mampu membentuk manusia yang bermotivasi kuat dan berani melihat perubahan sebagai suatu tantangan yang harus dihadapi. Salah satu pendekatan dalam peningkatan sumber daya manusia adalah melalui agama. Menurut Mangkunegara (2005:04) bahwa dalam hubungan dengan pencapaian kerja individu dan organisasi di era globalisasi perlu dilandaskan pendekatan psikologi dan organisasi, pendekatan budaya serta agama.

Islam menekankan kepada umatnya untuk bekerja. Sebagaimana dalam sabda-Nya bahwa "Bekerjalah untuk duniamu seakan-akan kamu hidup selamanya dan beribadahlah untuk akhiratmu seakan-akan kamu mati besok". Martoyo (2000:13) berpendapat manusia dalam aktivitas kebiasaannya memiliki semangat untuk mengerjakan sesuatu asalkan dapat menghasilkan sesuatu yang dianggap oleh dirinya memiliki suatu nilai yang sangat berharga, yang tujuannya jelas pasti untuk melangsungkan kehidupannya, rasa

\footnotetext{
1) Jurnal ini merupakan bagian dari skripsi yang ditulis oleh Bhirawa Anoraga, NIM:040914048, yang telah diuji pada tanggal 6 Juli 2015
} 
tentram, rasa aman dan sebagainya. Firman Allah SWT:

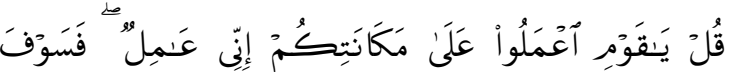

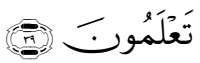

Qul yā qaumi'malū 'alā makānatikum innī 'āmil, fa saufa ta'lamūn

Artinya: Katakanlah, "Hai kaumku, Bekerjalah sesuai dengan keadaanmu, Sesungguhnya aku akan bekerja (pula), Maka kelak kamu akan mengetahui.(QS Az-Zumar: 39) ( Depag, 2012:462)

Ayat-ayat diatas menyuruh dan memotivasi kita untuk bekerja. Dengan bekerja kita bukan hanya mendapat penghasilan dan dapat memenuhi kebutuhan, tetapi juga untuk mencari nafkah yang merupakan bagian dari ibadah. Seorang muslim harus bekerja dengan niat yang ikhlas karena Allah SWT. Hendaknya para pekerja dapat meningkatkan tujuan akhir dari pekerjaan yang mereka lakukan, karena tujuan utama dari bekerja menurut Islam adalah memperoleh keridhaan Allah SWT.

Istilah kerja dalam Islam bukan semata mata merujuk kepada mencari rezeki untuk menghidupi diri dan keluarga dengan menghabiskan waktu siang maupun malam dan tak lenal lelah, tetapi kerja mencakup segala bentuk amalan atau pekerjaan yang mempunyai unsur kebaikan dan keberkahan bagi diri sendiri, keluarga, maupun masyarakat di sekitarnya.
Ali dan Owaihan

(2008)

mengatakan bahwa sejak awal masa muslim, khususnya umat muslim telah menawarkan pandangan pada pekerjaan dan telah merumuskan secara jelas mengenai konsep etos kerja. Ełos kerja erat kaitannya dengan nilai-nilai kerja yang diyakini dan dimiliki oleh seorang karyawan, yang nantinya mempengaruhi sikap karyawan dalam bekerja.

Tasmara

(2002:16)

berpendapat bahwa dengan etos kerja yang bersumber dari keyakinan Al-Qur'an ada semacam keterpanggilan yang sangat kuat dari lubuk hatinya, untuk menunjukkan hasil kerja kerasnya yang berkualitas.

Islam sebagai agama yang sempurna, sistem keimanan dan aqidah yang diyakini oleh para pemeluknya yaitu muslim, juga mengatur mengenai etos kerja, mendorong dan mengutus umatnya untuk memiliki semangat kerja dan beramal, tanpa mengeluh yang menunjukkan adanya kepuasan bagi diri sendiri.

Motivasi kerja Islam dan Ełos kerja Islam sangat penting untuk meningkatkan kualitas sumber daya manusia dalam perusahaan, terutama lembaga kevangan seperti bank yang berbasis Syariah. Bank syariah sangat mengandalkan sumber daya manusia sebagai poros untuk menjalankan kegiatannya, oleh karena itu sumber daya manusia dalam suatu bank syariah wajib 
memiliki motivasi kerja Islam dan etos kerja Islam yang baik untuk menghasilkan kinerja yang memuaskan.

Bank Jatim syariah (BJS) dilandasi filosofi pelayanan dan kepercayaan untuk mengatasi masalah perekonomian di masyarakat luas. Sebagai lembaga kevangan yang terpercaya Bank Jatim Syariah membangun karakter Sumber Daya Insani (SDI) dengan prinsip luhur yang dicontohkan oleh Rasulullah SAW yaitu insan BJS yang beriman, cerdas, amanah, jujur, berkomunikasi dengan baik. Pribadi demikian diharapkan akan memiliki empati, edifikasi, dan berorientasi hasil yang sepenuhnya mengutamakan layanan fokus kepada nasabah.

Dari latar belakang di atas dapat dijelaskan, motivasi kerja Islam dan Ełos kerja Islam yang baik sangat diperlukan oleh karyawan. Penelitian ini bertujuan untuk mengetahui pengaruh motivasi kerja Islam terhadap etos kerja Islam karyawan Bank Jatim Syariah cabang Surabaya.

\section{Rumusan Masalah}

Berdasarkan uraian pada latar belakang diatas, maka dapat dirumuskan bahwa masalah yang ingin diteliti adalah "Apakah Motivasi Kerja Islam memiliki pengaruh secara signifikan terhadap Ełos Kerja Islam Karyawan Bank Jatim Syariah cabang Surabaya?"

\section{Tujuan Penelitian}

Berdasarkan latar belakang serta rumusan masalah yang dikemukakan diatas maka dapat disebutkan bahwa tujuan penelitian ini adalah untuk mengetahui apakah terdapat pengaruh signifikan antara Motivasi Kerja Islam terhadap Ełos Kerja Islam Karyawan Bank Jatim Syariah cabang Surabaya.

\section{LANDASAN TEORI}

\section{Motivasi Kerja Islam}

Motivasi berasal dari kata latin "movere" yang berarti dorongan atau daya penggerak. Menurut Mathis (2006:71) motivasi merupakan hasrat didalam diri seseorang yang menyebabkan orang tersebut melakukan tindakan. Motivasi diartikan sebagai keadaan dalam pribadi seseorang yang mendorong keinginan individu untuk melakukan kegiatankegiatan tertentu guna mencapai tujuan (Handoko, 2001:25).

Mencari nafkah dalam islam adalah sebuah kewajiban. Islam adalah agama yang fitrah, yang sesuai dengan kebutuhan manusia, diantaranya adalah kebutuhan fisik. Salah satu cara memenuhi kebutuhan fisik itu ialah dengan bekerja. Motivasi kerja dalam islam bukanlah untuk mengejar hidup hedonis, bukan juga untuk status, apalagi mengejar kekayaan dengan segala cara. Dengan demikian, motivasi kerja islam bukan hanya untuk memenuhi nafkah semata tetapi sebagai kewajiban beribadah kepada Allah SWT setelah ibadah fardhu lainnya.

Motivasi kerja islam adalah komitmen terkait pekerjaan yang berasal dari hubungan seorang karyawan dengan tuhannya (Rahman, 1995). Selama ini 
banyak orang bekerja untuk mengejar materi belaka demi kepentingan duniawi, mereka tak sedikitpun mempedulikan kepentingan akhirat kelak. Oleh karena itu sebaiknya pekerja perlu memiliki motivasi yang dapat memberikan kepribadian yang baik dan dibenarkan oleh Islam.

\section{Etos Kerja Islam}

Kata etos berasal dari bahasa Yunani (ethos) yang memberikan arti sikap, kepribadian, watak, karakter serta keyakinan atas sesuatu. Etos dibentuk oleh berbagai kebiasaan, pengaruh budaya, serta sistem nilai yang diyakininya. Menurut Kamus Umum Bahasa Indonesia, etos adalah ilmu pengetahuan tentang asas-asas akhlak (moral).

Etos kerja Islam menurut Asifudin (2004:234) merupakan karakter dan kebiasaan manusia berkenaan dengan kerja, terpancar dari sistem keimanan/aqidah Islam yang merupakan sikap hidup mendasar terhadapnya. Menurut Tasmara (2002:26), etos kerja Islam adalah suatu upaya yang sungguhsungguh, dengan mengerahkan seluruh aset, pikiran, dan zikirnya untuk mengaktualisasikan atau menampakan arti dirinya sebagai hamba Allah yang harus menundukan dunia dan menempatkan dirinya sebagai bagian dari masyarakat yang terbaik (khairul ummah) atau dengan kata lain dapat juga kita katakan bahwa hanya dengan bekerja manusia itu memanusiakan dirinya. Etos kerja Islami adalah akhlak dalam bekerja sesuai dengan nilai-nilai islam sehingga dalam melaksanakannya tidak perlu lagi di pikir-pikir karena jiwanya sudah meyakini sebagai sesuatu yang baik dan benar.

Ełos kerja islami itu sendiri berasal dari Al-Qur'an dan Hadits Nabi Muhammad SAW, yang mengajarkan bahwa dengan bekerja keras yang disebabkan karena telah berbuat dosa akan diampuni oleh Allah SWT dan tidak ada makanan yang lebih baik dibandingkan apa yang dimakan dari hasil jerih payahnya atau kerja kerasnya. Ełos kerja Islam memberikan pandangan mengenai dedikasi yang tinggi dalam bekerja keras sebagai sebuah kewajiban yang wajib. Usaha yang cukup haruslah menjadi bagian dari kerja yang dilakukan seseorang, yang terlihat sebagai kewajiban individu yang cakap (Tasmara, 2002:25).

\section{Model Analisis}

Berdasarkan hipotesis di atas, maka dalam penelitian ini digunakan analisis dengan kerangka kerja penelitian untuk menjelaskan hubungan spesifik antara variabel eksogen dan variabel endogen. Model analisis dari penelitian ini adalah sebagai berikut:

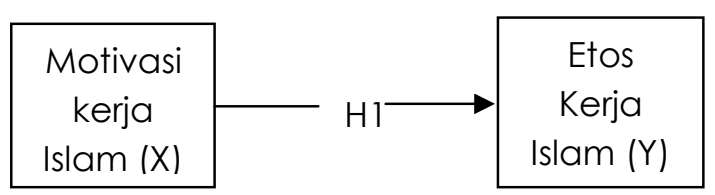

Sumber: Diolah dari berbagai sumber.

Gambar 1.

Model Analisis 


\section{METODE PENELITIAN}

Pendekatan penelitian yang digunakan dalam penelitian ini adalah pendekatan kuantitatif, yang bertujuan untuk menguji hipotesis, dengan data yang terukur dan menghasilkan kesimpulan yang dapat digeneralisir. Langkah awal dalam melakukan penelitian kuantitatif dimulai dengan menentukan hipotesis, langkah selanjutnya membuat model analisis, indentifikasi variabel, definisi operasional, pengumpulan data (primer maupun sekunder) berdasarkan populasi dan sampel penelitian, serta melakukan analisis. Variabel yang digunakan dalam penelitian ini dapat diidentifikasikan menjadi 2 (dua) variabel, yaitu:

a. Variabel independen (X), yaitu motivasi kerja Islam.

b. Variabel dependen (Y), yaitu etos kerja Islam.

Berdasarkan variabel-variabel yang digunakan, maka hubungan antar variabel dapat dinyatakan dalam fungsi sebagai berikut:

$$
Y=f(X)
$$

Bentuk persamaan regresi dapat dirumuskan sebagai berikut :

$$
Y=\beta_{0}+\beta_{1} X+\varepsilon
$$

Keterangan:

$$
\begin{array}{ll}
Y & =\text { Ełos Kerja Islam } \\
X & =\text { Motivasi Kerja Islam } \\
\beta_{0} & =\text { Konstanta } \\
\beta_{1} & =\text { Koefisien Regresi } \\
\varepsilon & =\text { Variabel Error }
\end{array}
$$

Dari model analisa regresi linear yang digunakan, terdapat beberapa asumsi klasik yang dapat digunakan untuk mengestimasi hasil agar tidak ada penyimpangan sehingga dapat memberikan informasi yang sesuai dengan data yang tersedia. Asumsi klasik tersebut adalah, uji heteroskedastisitas, dan uji normalitas.

\section{Definisi Operasional}

\section{Motivasi Kerja Islam (X)}

Motivasi kerja Islam adalah komitmen terkait pekerjaan yang berasal dari hubungan seorang karyawan dengan tuhannya (Rahman, 1995). Selama ini banyak orang bekerja untuk mengejar materi belaka demi kepentingan duniawi, mereka tak sedikitpun mempedulikan kepentingan akhirat kelak. Oleh karena itu sebaiknya pekerja perlu memiliki motivasi yang dapat memberikan kepribadian yang baik dan dibenarkan oleh Islam, dan menurut Saleh (2009:65) ciri-ciri orang yang memiliki motivasi bekerja menurut Islam adalah sebagai berikut:

1. Niat baik dan benar (mengharap ridha Allah SWT)

Seseorang harus mengetahui apa niat dan motivasi bekerja, niat inilah yang akan menentukan arah pekerjaanya. Jika niat bekerja hanya untuk mendapatkan gaji, maka hanya itulah yang akan dia dapat. Akan tetapi jika niatnya adalah bekerja untuk mendapatkan harta halal, menafkahi keluarga, dan semata-mata untuk mendapatkan ridha Allah SWT, maka dia akan mendapatkan sebagaimana yang 
dia niatkan. Ciri-ciri orang yang bekerja dengan niat baik dan benar untuk mengharap ridha Allah SWT adalah:

a. Mengharapkan pahala sebagai imbalan atas pekerjaan yang dilakukan.

b. Rezeki yang halal merupakan salah satu dorongan untuk bekerja.

c. Memandang pekerjaannya sebagai bentuk ibadah kepada Allah SWT.

d. Bekerja sebagai bentuk pengabdian kepada Allah SWT.

2. Takwa dalam bekerja

Terdapat dua pengertian dari takwa yang dimaksud, yang pertama adalah taat melaksanakan perintah dan menjauhi segala bentuk larangan-Nya. Kedua, sikap tanggung jawab seorang muslim terhadap keimanan yang telah diyakini dan diikrarkannya. Orang yang bertakwa dalam bekerja adalah orang yang mampu bertanggung jawab terhadap segala tugas yang telah diamanahkan kepadanya. Orang yang bertakwa juga akan selalu menampilkan sikap-sikap positif, karena itu orang yang bertakwa dalam bekerja akan menampilkan sikap-sikap sebagai berikut:

a. Bekerja dengan cara terbaik sebagai wujud tanggung jawab terhadap kerja dan tugas yang telah diamanahkan padanya.

b. Menjauhi segala bentuk kemungkaran untuk dirinya dan orang lain dalam bekerja, seperti tidak bermalas-malasan dan merugikan rekan kerja.

c. Taat pada aturan yang berlaku di tempat kerjanya.

d. Selalu ingin melakukan yang terbaik dalam pekerjaannya.

3. Ikhlas dalam bekerja

Ikhlas adalah syarat diterimanya amal perbuatan manusia disisi Allah SWT. Suatu pekerjaan yang dilakukan dengan keikhlasan maka akan mendatangkan rahmat dari Allah SWT. Ciri orang yang bekerja dengan ikhlas adalah:

a. Bekerja semata-mata mengharapkan ridha Allah SWT.

b. Bekerja dengan ikhlas meskipun pekerjaan itu berat.

c. Penuh semangat dalam mengerjakan pekerjaannya.

d. Tidak melakukan pamrih dan riya.

\section{Etos Kerja Islam (Y)}

Menurut Asifudin (2004:101), ciri-ciri etos kerja Islam digali dan dirumuskan berdasarkan konsep iman dan amal shaleh dengan memberikan prioritas penekanan pada etos kerja Islam beserta prinsip-prinsip dasarnya sebagai fokus. Karena etos kerja apapun menurut Quran 
tidak dapat menjadi Islam bila tidak dilandaskan pada konsep iman dan amal shaleh. Lanjut Asifudin (2004:104) bahwa dari konsep iman, ilmu dan amal, dapat digali dan dirumuskan karakteristikkarakteristik etos kerja Islam:

A. Kerja merupakan penjabaran aqidah, meliputi :

1. Dapat menerima kenyataan berkenaan dengan diri sendiri, orang lain, dan alam.

2. Berperilaku wajar tidak dibuatbuat.

3. Berpendirian teguh dan tidak mudah terpengaruh.

4. Konsentrasi perbuatan tidak pada ego, melainkan pada kewajiban dan rasa tanggung jawab.

5. Memiliki kesegaran apresiasi terhadap alam dan kehidupan.

6. Mempunyai kehidupan motivasi yang terutama digerakan oleh motivasi ibadah dan hasrat memperoleh kehidupan surgawi di akhirat kelak.

B. Kerja dilandasi ilmu, meliputi :

1. Pernah atau sering mengalami pengalaman puncak.

2. Mampu membedakan antara tujuan benar dan salah, baik dan buruk.

3. Menyukai efisiensi dan efektivitas kerja.

4. Mempunyai disiplin pribadi.

C. Kerja dengan meneladani sifat-sifat ilahi serta mengikuti petunjukpetunjukNya, meliputi :
1. Memiliki jiwa sosial dan sifat demokratis.

2. Mengembangkan kreativitas.

3. Percaya pada potensi insani karunia Tuhan untuk melaksanakan tugasnya: bertawakkal kepada Allah SWT.

4. Mengembangkan sikap hidup kritis konstruktif.

\section{Populasi dan Sampel}

Populasi adalah kumpulan individu dengan kualitas serta ciri-ciri yang sebelumnya sudah ditetapkan (Nazir dalam Anshori dan Iswati, 2009:92). Sugiyono (2010:117) menjelaskan bahwa, populasi adalah wilayah generalisasi yang terdiri atas: obyek/subyek yang mempunyai kualitas dan karakteristik tertentu yang ditetapkan oleh peneliti untuk dipelajari dan kemudian ditarik kesimpulan. Populasi dalam penelitian ini adalah seluruh karyawan Bank Jatim Syariah Cabang Surabaya.

Sampel adalah bagian dari jumlah dan karakteristik yang dimiliki oleh populasi (Sugiyono, 2010: 118). Jumlah sampel dalam penelitian ini sebanyak 54 responden. Responden dalam penelitian ini adalah karyawan Bank Jatim Syariah Cabang Surabaya.

\section{HASIL DAN PEMBAHASAN}

Hasil Uji Regresi Linear Sederhana

Tabel 1.

Hasil Uji Regresi Linear Sederhana

\begin{tabular}{|l|l|l|l|l|}
\hline Variabel & \multicolumn{2}{|c|}{ Koefisien } & \multirow{2}{*}{ t hit. } & Sign. \\
\cline { 2 - 3 } & $\begin{array}{l}\text { Koef. } \\
\text { Reg. }\end{array}$ & Beta & & \\
& & & \\
\hline
\end{tabular}




\begin{tabular}{|l|l|l|l|l|}
\hline Konstanta & 2.739 & & 6.476 & 0,000 \\
\hline Stres Kerja & 0.353 & 0.446 & 3.592 & 0,001 \\
\hline Multiple $\mathrm{R}=0,446 \quad \mathrm{~N}=54$ \\
R Square $=0,199 \quad$ Sign $=0,000$ \\
\hline
\end{tabular}

Sumber: Hasil Penelitian. 2015 (diolah)

Nilai dari koefisien determinasi dari hasil perhitungan adalah 0,446 yang berarti bahwa sebesar $44,6 \%$ etos kerja Islam (variabel endogen) mampu dijelaskan oleh variabel eksogen yang dimasukkan dalam model, yaitu motivasi kerja Islami, sedangkan $55,4 \%$ dijelaskan oleh variabel lain yang tidak dimasukkan dalam model.

Berdasarkan hasil analisis regresi linear sederhana yang dilakukan pada penelitian ini diperoleh nilai koefisien korelasi berganda atau Multiple (R) sebesar 0,446. Nilai $R$ sebesar 0,446 menunjukkan adanya hubungan yang cukup tinggi antara variabel bebas $(X)$ dengan variabel tergantung $(Y)$.

\section{Hasil Regresi}

Tabel 2.

Hasil Uji Regresi Secara Parsial (Uji †)

\begin{tabular}{|l|c|c|}
\hline \multicolumn{1}{|c|}{ Variabel } & T & $\begin{array}{c}\text { Tingkat } \\
\text { signifikansi }\end{array}$ \\
\hline $\begin{array}{l}\text { Motivasi } \\
\text { Kerja Islam }\end{array}$ & 3.592 & 0.001 \\
\hline
\end{tabular}

Sumber: Hasil Penelitian. 2015 (diolah)

Berdasarkan Tabel diatas, nilai uji † variabel Motivasi kerja Islami (X) sebesar 3.592 dengan tingkat signifikasi 0,001 . Nilai signifikasi ini lebih kecil dari 0,05, sehingga dapat ditarik kesimpulan, yaitu variabel Motivasi kerja Islami (X) mempunyai pengaruh terhadap Etos kerja Islami $(Y)$.

\section{Pembahasan}

Berdasarkan hasil analisis koefisien korelasi dalam penelitian ini, disebutkan bahwa variabel motivasi kerja Islam (X) berpengaruh signifikan dengan variabel etos kerja Islam (Y). Hubungan antar variabel juga menunjukkan tanda positif. Hubungan yang positif antar variabel tersebut dapat diartikan bahwa setiap peningkatan variabel bebas akan berpengaruh terhadap peningkatan variabel tergantung, begitu pula sebaliknya setiap penurunan variabel bebas akan berpengaruh pula pada penurunan variabel tergantung.

Berdasarkan hasil pengolahan data dari 54 responden, menunjukan bahwa secara keseluruhan rata-rata tanggapan responden pada motivasi kerja Islam termasuk sangat tinggi, dengan dengan tanggapan responden yang termasuk sangat tinggi sebanyak 11 indikator yang meliputi:

1. Rezeki yang halal merupakan salah satu dorongan untuk bekerja (X1.2).

2. Memandang pekerjaannya sebagai bentuk ibadah kepada Allah SWT (X1.3).

3. Bekerja sebagai bentuk pengabdian kepada Allah SWT (X1.4).

4. Bekerja dengan cara terbaik sebagai wujud tanggung jawab terhadap kerja dan tugas yang telah diamanahkan padanya (X1.5). 
5. Menjauhi segala bentuk kemungkaran untuk dirinya dan orang lain dalam bekerja, seperti tidak bermalas-malasan dan merugikan rekan kerja (X1.6).

6. Taat pada aturan yang berlaku di tempat kerjanya (X1.7).

7. Selalu ingin melakukan yang terbaik dalam pekerjaannya (X1.8).

8. Bekerja semata-mata mengharapkan ridha Allah SWT (X1.9).

9. Bekerja dengan ikhlas meskipun pekerjaan itu berat (X1.10).

10. Penuh semangat dalam mengerjakan pekerjaannya (X1.11).

11. Tidak melakukan pamrih dan ria (X.12).

Selanjutnya tanggapan responden yang termasuk tinggi hanya meliputi 1 indikator yaitu:

1. Mengharapkan pahala sebagai imbalan atas pekerjaan yang dilakukan.

Oleh karena itu dari hasil analisis data tersebut dapat menunjukan bahwa motivasi kerja Islam termasuk sangat tinggi.

Uji yang dilakukan yaitu uji † untuk mengetahui apakah variabel-variabel tersebut memiliki pengaruh yang signifikan. Hasil uji regresi menunjukkan besar nilai t sebesar 3,592 dengan tingkat signifikan $\leq 0,05$ yaitu 0,001 . Hasil tersebut menunjukan bahwa tinggi rendahnya etos kerja Islami karyawan Bank Jatim Syariah cabang surabaya salah satunya dipengaruhi oleh faktor motivasi kerja Islam. Dengan demikian, hasil analisis ini mengindikasikan bahwa hipotesis dapat diterima, artinya motivasi kerja Islami mempunyai pengaruh positif yang signifikan terhadap etos kerja Islam karyawan Bank Jatim Syariah cabang Surabaya.

Adapun besarnya nilai koefisien determinasi $\left(R^{2}\right)$, yaitu sebesar 0,446 , yang berarti bahwa motivasi kerja Islam mempunyai pengaruh terhadap etos kerja Islam karyawan Bank Jatim Syariah cabang Surabaya sebesar 44,6\%, sedangkan sisanya yaitu sebesar $55,4 \%$ dipengaruhi variabel lain yang tidak diteliti.

Selain itu dukungan terhadap hasil penelitian sebelumnya dari Sutisna (2008) yang berjudul analisis hubungan motivasi kerja dengan etos kerja karyawan, menunjukkan bahwa motivasi kerja berpengaruh positif terhadap etos kerja karyawan. antara motivasi kerja dengan etos kerja karyawan mempunyai hubungan yang kuat, yaitu semakin baik motivasi kerja seorang karyawan maka akan semakin baik pula etos kerja karyawan tersebut.

\section{SIMPULAN}

\section{Simpulan}

Simpulan penelitian Pengaruh Motivasi Kerja Islam terhadap Ełos Kerja Islam Karyawan Bank Jatim Syariah cabang Surabaya adalah tingkat motivasi kerja Islam berpengaruh langsung, positif, 
dan signifikan terhadap etos kerja Islam karyawan Bank Jatim Syariah cabang Surabaya. Hal ini menunjukkan bahwa hipotesis yang menyatakan motivasi kerja Islam berpengaruh signifikan terhadap etos kerja Islam karyawan Bank Jatim Syariah cabang Surabaya adalah diterima. Secara teoritis temuan ini mengandung makna bahwa motivasi kerja Islam merupakan instrumen penting untung membentuk Etos kerja Islam karyawan Bank Jatim Syariah cabang Surabaya. Semakin tinggi tingkat motivasi kerja Islam, akan semakin baik pula Etos kerja Islam karyawan.

\section{Saran}

Untuk Bank Jatim Syariah cabang Surabaya

a. Sesuai dengan analisis data deskripsi variabel motivasi kerja Islam yaitu mengharapkan pahala sebagai imbalan atas pekerjaan yang dilakukan (X1.1) dengan nilai mean terendah, maka dapat disarankan kepada karyawan Bank Jatim Syariah cabang Surabaya agar meningkatkan motivasinya dalam bekerja, yang terutama adalah mengharapkan pahala sebagai imbalan atas pekerjaan yang dilakukan. Motivasi kerja lainnya seperti upah atau bekerja sebagai mata pencaharian adalah kepentingan di dunia, oleh karena itu akan lebih baik lagi jika kita juga mementingkan kepentingan di akhirat kelak. Bekerja adalah salah satu ibadah kita kepada Allah SWT sebagai tabungan untuk memperoleh kehidupan surgawi di akhirat kelak. Hal ini disarankan agar karyawan Bank Jatim Syariah cabang Surabaya dapat memiliki motivasi kerja Islami yang tinggi dengan tujuan agar kepentingan di dunia maupun di akhirat dapat terpenuhi.

b. Sesuai dengan analisis data deskripsi variabel etos kerja Islam yaitu menyukai efektivitas telah tercapai dalam bekerja (Y1.10) dengan nilai mean terendah, maka dapat disarankan kepada karyawan Bank Jatim Syariah cabang Surabaya agar bekerja lebih giat, tekun dan menyelesaikan pekerjaan dengan tepat waktu agar efektivitas dalam bekerja dapat tercapai dan hasil pekerjaan dapat termaksimalkan dengan baik.

Untuk Penelitian Selanjutnya

Peneliti berharap penelitian ini dapat digunakan sebagai bahan acuan untuk melakukakan penelitian selanjutnya. Peneliti menyadari bahwa masih banyak keterbatasan maupun kekurangan yang terdapat dalam penelitian ini. keterbatasan penelitian ini akan memberikan peluang bagi penelitian selanjutnya untuk melakukan pengembangan dan peningkatan motivasi kerja Islami dan etos kerja Islami 
secara lebih luas. Penelitian dengan menguji dan menambahkan variabel intervening diantara variabel motivasi kerja Islami dan etos kerja Islami akan menjadi agenda penelitian yang menarik untuk diteliti lebih jauh sehingga akan menambah wawasan yang lebih luas terkait dengan manajemen sumber daya insani.

\section{DAFTAR PUSTAKA}

Anshori, Muslich dan Sri Iswati. 2009. Metodologi Penelitiian Kuantitatif. Surabaya: Airlangga University Press.

Ali, J.A. and Al-Owaihan, A. 2008. "Is/amic work ethic: a critical review" CrossCultural Management an International Journal. Vol. 15 No. 1.

Asifudin, Ahmad. 2004. Etos Kerja Islami. Yogyakarta: UII Press.

Departemen Agama RI. 2012. Al-Qur'an dan Terjemahannya dengan Transliterasi. Semarang: PT Karya Toha Putra.

Handoko, T.H. 2001. Manajemen Personalia dan Sumber Daya Manusia. Yogyakarta: BPFE Press.

Mangkunegara, Anwar Prabowo, 2005. Perencanaan dan Pengembangan Sumber Daya Manusia. Bandung: PT. Refika Aditama.

Martoyo, Susilo. 2000. Manajemen Sumber Daya Manusia. Yogyakarta: BPFE.

Mathis, Robert L. dan Jackson. John H. 2006. Human Resource Management (Manajemen
Sumber Daya Manusia). Edisi 10. Jakarta: Salemba Empat.

Rahman, abdel rahman AA. 1995. An islamic perspective on organizational motivation. The american journal of islamic social science vol 12 no 2.

Saleh, Akh. Muwafik. 2009. Bekerja dengan Hati Nurani. Jakarta: Erlangga.

Sugiyono. 2010. Metode Penelitian Bisnis: Pendekatan Kuantitatif, Kualitatif, dan R\&D. Bandung: Alfabeta.

Tasmara, Toto. 2002. Membudayakan Etos Kerja Islami. Jakarta: Gema Insani. 